\title{
Import Substitution Priorities for Ensuring the Economic Security of Russian regions
}

\author{
Irina Golova* \\ Sector of Social Innovation, Institute of Economics of the Ural Branch of the Russian Academy of \\ Sciences, 620014, Moskovskaya St., 29, Ekaterinburg, Russian Federation
}

\begin{abstract}
The paper proposes a methodological approach to improving the Russian import substitution policy, which considers innovative import substitution as an important aspect of new industrialization of the country. The study analyzes problems and contradictions present in the high-tech production sector. The sectoral approach to solving the import substitution problems in Russia has proved to be unpromising. Thus, Russian regions have to implement the import substitution model, aimed at the comprehensive transformation of the production ecosystem. The research revealed the directions of improving the mechanisms of import substitution to ensure the economic security in the long term. Favorable conditions for the development of innovative import substitution in Russian regions were analyzed and compared using the author's methodology; a group of leading regions was determined. The article describes ways to reduce institutional barriers between science and production to implement innovative activities, considering the specificity of Russian regions.
\end{abstract}

\section{Innovative import substitution as a direction of increasing the economic security of Russian regions}

Due to the deindustrialization of Russian regions accompanied by an increasing technological backwardness of various industries, Russia relies heavily on foreign technology suppliers. Nowadays, the country's import dependence is approximately $90 \%$ in the field of machine tools, tools and aircraft construction, and more than $80 \%$ in radioelectronic devices [1]. China dominates the Russian telecommunications market (almost $80 \%$ of sales), while the share of domestic companies does not exceed $8 \%$ [2]. The current situation poses a serious threat to the economic security of the country, especially considering the tightening of international sanctions.

Import substitution is usually understood as an activity ensuring economic sovereignty of the country by reducing dependence on foreign supplies [3]. Initially, the import substitution strategy was mainly considered as a way to overcome technological backwardness in the context of catch-up modernization $[4,5]$. Simultaneously, some neoKeynesians draw attention to the important role of import substitution in stimulating the development of local economies, giving them a fresh impetus [6]. The United States, the

* Corresponding author: irina_golova@mail.ru 
European Union countries, and other regions of the world are actively using the import substitution possibilities to solve the problems of reindustrialization [7].

Nowadays, there is an understanding that, to ensure the economic security, import substitution should be an essential element of industrial policy of any country, regardless of its technological development [8]. Import substitution has a two-fold task: a) to ensure the economic independence of the country, b) to timely upgrade its production, considering promising science and technology developments. Accordingly, it is necessary to distinguish two aspects in the structure of import substitution. The first one is common import substitution, aimed at reducing dependence on foreign suppliers by using production technologies available in the country and (or) copying foreign products. The second is innovative import substitution, characterized by constant monitoring of technology markets, analysis of scientific results, and development of advanced technologies; knowledge and experience gained are necessary for timely upgrading of production facilities and creation of competitive alternative products and new technologies. Both aspects of import substitution are important for ensuring the economic security; however, the innovative aspect is a priority for countries lagging behind in technological development.

When innovative import substitution is considered as a specific area, it is possible to create a strategy to use import substitution as a tool to strengthen the internal competitiveness of the territory [9]. Simultaneously, countries relying on the catch-up strategy (including Russia that has to follow this strategy due to its technological backwardness) that are forced to start a technological development, should ensure quick transition from the borrowing stage to innovative import substitution. According to experts, the large-scale modernization of production facilities and software can increase the productivity of the Russian economy by approximately $40 \%$ [10, p. 15].

\section{Problems of implementation of innovative import substitution in Russian regions}

The modern import substitution policy in the Russian Federation is essentially vertical [11]. Nowadays, it is being implemented through state strategies and programs for developing certain industries, where technological backwardness threatens the economic security. The government adopted strategies for the development of transport engineering (2017), machine tool industry (2020), energy (2020) and implemented programs for the development of the electronics and radio electronics industry (2012), the pharmaceutical and medical industry (2014), the aviation industry (2014), the defense industry (2016), and various other industries. Government support measures for manufacturers include direct participation of the state in the implementation of promising investment projects, lease benefits, subsidized investment loans, etc. According to the Government of the Russian Federation, the total public funds allocated to import substitution in 2015-2020 are approximately 3 trillion rubles. Import substitution considerably succeeded in agriculture, oil and gas engineering, pharmaceuticals and other industries.

Simultaneously, considering technological backwardness of the country, international practice shows that the approach to solving import substitution problems of certain local industries is unproductive. At the beginning, such an approach applied in Latin American countries in the 1940s-1970s seemed to be efficient. However, the state implemented such import substitution policy in several industries, protected from competition with other manufacturers. Thus, due to these conditions and lack of suitable environment for innovative research and development, import substitution has exhausted itself, despite large-scale imports of technologies and involvement of foreign investors [5]. As a result, the state's mobilization of financial resources for the modernization of these industries not 
only did not help overcome technological backwardness, but also led to further development of negative economic processes.

According to the Global Competitiveness Index, Russia is currently ranked 43rd globally. As reported by the experts of the World Economic Forum, to increase its competitiveness and growth (competitive growth path), Russia has to improve such factors as the state of institutions, business dynamism, and skills $(73,53$, and 54 places in the ranking, respectively) [12]. While the countries that are technological leaders of the fifth technological mode have already reached the maturity stage and started shaping the sixth technological mode, almost $80 \%$ of the structure of the Russian industry is occupied by enterprises of the third and fourth technological modes [13, p. 12]. Additionally, borrowing of advanced foreign technologies is hampered by international sanctions.

Currently, more than half of the output of Russian manufacturing industry is produced in low-medium-tech sectors: metallurgy, coke and petroleum products, etc. (Table 1). Moreover, they are leaders in terms of important indicators for solving import substitution problems such as investment in fixed assets, technological innovation costs and innovative products. The share of high-tech industries in the total technological innovation costs is less than $18 \%$; the share of innovative products of high-tech manufacturing industries is approximately $13 \%$. In addition, a significant part of promising scientific developments is implemented in the defense complex, which currently functions as a self-sufficient structure isolated from the rest of the economy. Therefore, it is unlikely that these technologies can be implemented in the civilian sector as well.

Table 1. Indicators of industrial and innovative activity of Russian manufacturing industries by technological development, billion rubles (2018)

\begin{tabular}{|l|l|l|l|l|}
\hline Production type & $\begin{array}{l}\text { Shipping } \\
\text { volume }\end{array}$ & $\begin{array}{l}\text { Investment in } \\
\text { fixed assets }\end{array}$ & $\begin{array}{l}\text { Technological } \\
\text { innovation } \\
\text { costs }\end{array}$ & $\begin{array}{l}\text { Innovative } \\
\text { products }\end{array}$ \\
\hline Industry, total & 69621 & 6995 & 894 & 3693 \\
\hline $\begin{array}{l}\text { Manufacturing } \\
\text { industries }\end{array}$ & 44600 & 2585 & 672 & 2996 \\
\hline - high-tech & 3429 & 213 & 119 & 380 \\
\hline - high-medium-tech & 8066 & 738 & 141 & 894 \\
\hline - low-medium-tech & 23423 & 1078 & 313 & 1359 \\
\hline - low-tech & 9681 & 530 & 99 & 363 \\
\hline
\end{tabular}

Source: based on $[14,15]$.

The reason for the depressed state of innovation processes in the high-tech sector is obvious: the Russian system of economic regulation does not consider the characteristics of high-tech business, which, due to the specificity of this entrepreneurial activity, incurs increased costs for research and development, technological modernization of production and remuneration of highly skilled workers. Nowadays, the average profitability of extractive industries is more than $31 \%$, metallurgy is $26 \%$, and production of machinery and equipment is $3 \%$ [14]. In this context, it is necessary to consider price rather than technology competition of domestic high-tech civilian products. However, entrepreneurs are forced to choose cheaper and less advanced equipment (compared to the international one), which leads to the reinforcement of technological backwardness of the domestic economy in the future. 


\section{The choice of strategic priorities of innovative import substitution policy of Russian regions.}

To overcome the aforementioned problems, it is necessary to choose an import substitution model based on the modernization strategy, whose goal is "a comprehensive transformation, including not only individual technologies, but also business models, ecosystems, the rules of market functioning, and infrastructures" [16, p. 44]. This broad socio-economic approach to the problems of catch-up development proceeds from an understanding of the inextricable link between technological and social innovations. Additionally, it considers the provisions of the institutional theory that archaic institutional system is inconsistent with the goals and objectives of modernization and import substitution, thus hindering economic and technological growth [17]; this approach also takes into account the catch-up experience of various countries in the XX-XXI centuries. This strategy to achieve accelerated technological development was successfully implemented in Japan, Taiwan, China, and a number of other East Asian countries [18].

Considering the technological backwardness of Russia compared to leading industrial states and the strong scientific potential of the country, the first stage of import substitution should focus on creating conditions for borrowing advanced technologies. On the one hand, it is advisable to establish cooperation with international high-tech companies and accelerate the development of high-tech businesses of new technological modes. On the other, it is necessary to finance domestic research and development and shape the institutional environment for knowledge and technology transfer in order to use this scientific potential and create innovative developments with a high degree of novelty.

Russia is characterized by the vertically integrated production structure, which includes the overwhelming majority of medium and large enterprises. Nowadays, the import substitution strategy should rely on the sectoral principle. Simultaneously, technological development of the country requires the diversification of the production ecosystem and the strengthening of horizontal ties. Therefore, the import substitution strategy requires measures to develop high-tech business outside existing structures. New companies support the innovativeness of the society [19]. They are likely to apply innovative activities, as new enterprises are forced to reduce production costs to conquer markets. In turn, their development encourages established large corporations to introduce innovations in their industrial policy.

Additionally, the improvement of the production ecosystem of the country is impossible without measures to enhance the protection of property rights, control monopoly, reduce the tax burden on high-tech business, and significantly increase expenditures on science and education. The government should create development funds aimed at supporting the formation of new high-tech enterprises that are not associated with established business structures.

Russian Federation is one of the few countries where usually producers themselves finance industrial development. The share of own funds of enterprises in the total financing of investment projects is approximately $52 \%$, while the average share in the world is $23 \%$, and loans account for $67 \%$ [20, p. 18]. Considering the peculiarities of the domestic capital structure, it is essential to provide access to cheap loans for high-tech businesses.

Technical specialists are focused on identifying technological priorities of innovative import substitution based on the analysis of weak points and technical conditions of production. These priorities should consider the changing global technological landscape and the challenges of digitalization. Nowadays, the most promising areas are nanotechnology, advanced information and communication technologies, 3D printing, Internet of things, whole-genome synthesis, sun-powered chemistry, digital medicine, and others [21]. 
The rise of the digital society has significantly changed knowledge diffusion patterns. Today, information on new technologies circulates in transnational companies; it can usually be transferred only inside the production firms located in the country (region) [22]. Therefore, for the Russian import substitution strategy to succeed, it is necessary to establish and expand mutually beneficial contacts with international high-tech industries and companies.

To increase the efficiency of the import substitution strategy it is important to determine spatial priorities. The conducted calculations allowed identifying a group of that have the most favorable conditions for the establishment of domestic centers of innovative import substitution.

Based on official statistics for Russian regions, the following indicators were taken into consideration: the output of high-tech and medium-tech enterprises, the number of research and development (R\&D) employees, and exports of machinery and equipment. The total index was calculated as the weighted average of the normalized values of the examined indicators multiplied by the weight coefficients (1.0, 0.7 and 0.3 , respectively). The value of the weight coefficient for the number of $R \& D$ employees was taken equal to 0.7 , because the Russian science is secluded from the sphere of production, as the links between them are weakened. This observation is evidenced by the fact that in the United States companies provide two-thirds of the research and development expenditures, while in Russia approximately $90 \%$ of these expenditures are financed by the state budget $[23, \mathrm{p}$. 10]. The weight coefficient of exports of machinery and equipment is rather small due to the law export potential of the modern high-tech industry (nowadays, the share of Russia in hightech exports at the global level is less than $0.4 \%$ ). As the situation improves, the values of the weight coefficients can be adjusted.

Table 2 presents the list of 10 constituent entities of the Russian Federation that have the opportunities to develop innovative import substitution. Calculations were performed according to data of Federal State Statistics Service (Rosstat) [24].

Table 2. Constituent entities of the Russian Federation with the opportunity to develop innovative import substitution

\begin{tabular}{|l|l|l|l|l|}
\hline \multirow{2}{*}{$\begin{array}{l}\text { Entities of the } \\
\text { Russian Federation }\end{array}$} & Ranking position & $\begin{array}{l}\text { Output of } \\
\text { high- and } \\
\text { medium-tech } \\
\text { products }\end{array}$ & $\begin{array}{l}\text { Exports of } \\
\text { machines and } \\
\text { equipment }\end{array}$ & $\begin{array}{l}\text { Number of } \\
\text { R\&D } \\
\text { employees }\end{array}$ \\
\hline Moscow city & 1 & 1 & 1 & 1 \\
\hline St. Petersburg & 2 & 2 & 2 & 3 \\
\hline Moscow oblast & 3 & 3 & 3 & 2 \\
\hline Republic of Tatarstan & 4 & 4 & 12 & 8 \\
\hline Samara oblast & 5 & 5 & 9 & 12 \\
\hline $\begin{array}{l}\text { Nizhny Novgorod } \\
\text { oblast }\end{array}$ & 6 & 6 & 4 & 4 \\
\hline Kaluga oblast & 7 & 7 & 17 & 14 \\
\hline Sverdlovsk oblast & 8 & 10 & 5 & 6 \\
\hline Perm krai & 9 & 8 & 18 & 11 \\
\hline $\begin{array}{l}\text { Republic } \\
\text { Bashkortostan }\end{array}$ & 10 & 9 & 8 & 16 \\
\hline
\end{tabular}


The accumulated scientific potential is an important advantage, ensuring the implementation of the policy of innovative import substitution in Russia. Therefore, when developing an industrial ecosystem, it is necessary to create conditions for enhancing the interaction between business, science and education in terms of value chains. The main reasons for the low demand for Russian scientific developments are the lack of sufficient funds for scientific research in high-tech enterprises, personnel problems and disconnection between science and business. Today in Russian manufacturing companies, there are less than $10 \%$ of R\&D employees in science divisions, while in technologically developed countries, the value of this indicator is approximately $30-50 \%$ and more [25].

To overcome barriers between science and business and ensure continuous innovation development, it is advisable to create institutional conditions for expanding the channels of technology transfer from science to production. Financial incentives for joint innovation projects of scientific and industrial organizations are not sufficient. It is also necessary to establish the technological and organizational infrastructure for developing new industrial technologies in the country. For example, with support from the state, it is possible to create research and innovation centers to ensure import substitution in key economic sectors, which can be considered as an experimental ground for combining the efforts of science and business to produce competitive import-substituting goods and technologies. The establishment of innovation support centers focusing on industrial development and uniting science, business and the state is a worldwide practice [26].

In particular, Sverdlovsk oblast, ranked 8th in Table 2, has favorable conditions for creating an interregional innovation center for supporting import substitution in mechanical engineering, production of new materials and information technologies. However, considering the current division of powers and expenditure flows between the federal center and the constituent entities of the Russian Federation, it is not possible to create such centers, relying only on regional authorities.

The implementation of the proposed provisions requires a departure from the rigid sectoral approach to solving import substitution problems in Russia. Thus, it is necessary to develop a general concept, which considers import substitution as the first stage of the new industrialization of the country and affirms the priority of high-tech business development. Particular attention should be paid to the production ecosystem, improvement of its network structure and strengthening of the relationship between science and business in terms of value chains. This approach will enhance the attractiveness of Russia as a partner for international knowledge-intensive firms, which is necessary to increase sources for technology borrowing and create the conditions for continuous innovation development using domestic scientific research.

The reported study has been funded by RFBR according to the research project No. 20-010-00153 A "The Influence of the Innovation Import Substitution on Economic Security of the Region".

\section{References}

1. G. I. Idrisov, Towards modern industrial policy for Russia (Moscow: Gaidar institute publishing house, 2016)

2. L.A. Gamza, Russian and the Pacific, 3(109), 110-133 (2020)

3. E.G. Animitsa, P.E. Animitsa, A.A. Glumov, Econ. Reg., 3, 160-172 (2015)

4. P.M. Franko, Puzzle of Latin America Economic Development (Rowman \& Littlefield Publishers, Incorporated, 2007)

5. H. Bruton, J. Econ. Lit., 36, 903-936 (1998) 
6. H. Chenery, M. Syrquin, Patterns of Development 1950-1970 (Oxford: University Press, 1975)

7. S.A.Tolkachev, Industrial Policy in the Age of New Industrialization (Moscow: MAKS Press, 2015)

8. I.M. Golova, A.F. Sukhovey, Econ. Anal.: Theory and Practice, 19(8), 1388-1408 (2020)

9. M.E. Porter, The Competitive Advantage of Nations (New York: Free Press, 1990)

10. G.I. Idrisov, V.N. Knyaginin, A.L. Kudrin, E.S. Rozhkova, Vopr. Eco., 4, 5-25 (2018)

11. Y. Simachev, M. Kuzyk, N. Zudin, Foresight and STI Governance, 10(4), 25-45 (2016)

12. The Global Competitiveness Report 2019 https://www.weforum.org/reports/how-to-end-a-decade-of-lost-productivity-growth

13. E. Nikitskaya, Federalism, 4, 5-23 (2018)

14. Industrial Production in Russia (Moscow: Rosstat, 2019)

15. Indicators of Innovation in the Russian Federation (Moscow : HSE, 2020)

16. Yu. Kvashnin, M. Klinova, A. Nevskaya, E. Khesin, The European Union in the World Economy: Competitiveness Issues (Moscow : IMEMO, 2020)

17. D.C. North, World Dev., 17(9), 1319-1332 (1989)

18. N.Sh. Vatolkina, N.V. Gorbunova, St. Petersburg State Polytechnical Uni. J. Econ., 6(233), 29-39 (2015)

19. J.A. Schumpeter, Capitalism, Socialism, and Democracy (New York: Harper and Brothers, 1942)

20. G. Samodurov, D. Lakhtyukhov, Stankoinstrument, 2, 12-18 (2020)

21. Top 10 Emerging Technologies of 2020. Special Report (2020) http://www3.weforum.org/docs/WEF_Top_10_Emerging_Technologies_2020.pdf

22. R.E. Baldwin, The Great Convergence: Information Technology and the New Globalization (Cambridge, Massachusetts: The Belknap Press of Harvard University Press, 2016)

23. N.I. Ivanova, Econ., Taxes \& Law, 12(3), 6-16 (2019)

24. Regions of Russia. Socio-economic indicators (Moscow: Rosstat, 2020)

25. A.F. Sukhovey, I.M. Golova, The innovative component of socio-economic development of the region (Ekaterinburg: Institute of Economics UB RAS, 2019)

26. E.B. Lenchuk, Stud. on Rus. Econ. Dev., 3, 132-146 (2016) 